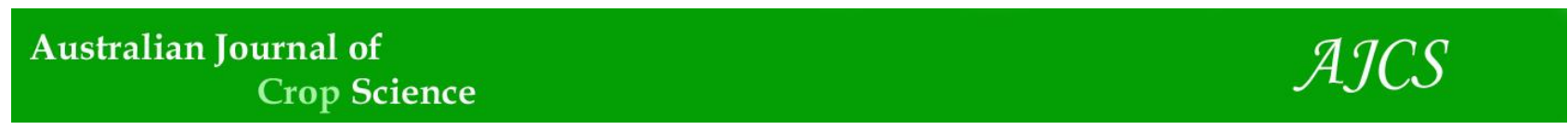

AJCS 15(08):1095-1101 (2021)

ISSN:1835-2707

doi: 10.21475/ajcs.21.15.08.p2711

\title{
Treated municipal wastewater reuse for eggplant irrigation
}

\author{
Marie Therese Abi Saab ${ }^{1 *}$, Claude Daou ${ }^{2}$, Isam Bashour ${ }^{3}$, Antoun Maacaron ${ }^{4}$, Salim Fahed ${ }^{1}$, Dany \\ Romanos $^{1}$, Yara Khairallah ${ }^{1}$, Nada Lebbous ${ }^{1}$, Celine Hajjar ${ }^{1}$ Roula Abi Saad $^{1}$, Caroline Ojeil ${ }^{1}$, Mohamed \\ Houssemeddine Sellami ${ }^{5}$, Salim Roukoz ${ }^{6}$, Maher Salman ${ }^{7}$
}

\author{
${ }^{1}$ Lebanese Agricultural Research Institute, P.O. Box 90-1965, Fanar, Lebanon \\ ${ }^{2}$ Lebanese University, Faculty of Sciences, Fanar, Lebanon \\ ${ }^{3}$ American University of Beirut, Beirut, Lebanon \\ ${ }^{4}$ Food and Agriculture Organization (FAO), Beirut, Lebanon \\ ${ }^{5}$ National Research Council of Italy, Institute for Agricultural and Forestry Systems in the Mediterranean (CNR- \\ I.S.A.FO.M.), Via Patacca, 85, - 80056 - Ercolano (NA) Italy \\ ${ }^{6}$ Ministry of Agriculture, Beirut, Lebanon; (7) Food and Agricultural Organization (FAO), Rome, Italy
}

\section{*Corresponding author: mtabisaab@lari.gov.lb}

\begin{abstract}
In the Bekaa Valley of Lebanon, the availability of freshwater is limited and therefore farmers must start using alternative water sources such as treated wastewater for irrigating crops. The present study is of great importance, since it provides evidence of some on-farm options that farmers can adopt when irrigating with treated effluent, in order to minimize the health risks. Eggplant was grown under two water quality regimes (Freshwater (FW) and treated wastewater (TW)) and two agronomic practices (no mulch $\left(\mathrm{N} \_\mathrm{Mu}\right)$ and use of plastic mulch $\left.(\mathrm{Mu})\right)$. Treatments were arranged in a split plot design with four replicates. Water quality regime was the main plot factor, while agronomic practices were the subplot factors. Water quality, soil, the marketable yield and other parameters were measured. Fruit samples were evaluated for bacterial contamination. The drip line performance was monitored. The study results revealed that the treatment with treated effluent gave more fruits. $\mathrm{m}^{-2}$, yield and mean fruit weight than the treatment using fresh water irrigation, with an increase of $3.98 \%, 10.74 \%$ and $5.63 \%$, respectively. In addition, the use of mulch (Mu) resulted in an increase in yield $(24.23 \%)$ and number of fruits $(14.11 \%)$. Concerning the emitters' performance and sensitivity to clogging, discharge reduction rate $(\mathrm{Rd}=6.75 \%)$ for drippers delivering TW was lower than the admissible value of $20 \%$ discharge variation, indicating that the quality of water has little effect on emitter performance. Concerning bacterial contamination of fruits, irrigation with treated wastewater showed no contamination in terms of fecal streptococci, salmonella or $E$. coli. However, the fruits were contaminated with fecal coliforms that were present at a concentration less than $200 \mathrm{CFU} .100 \mathrm{~g}^{-1}$. Following the World Health Organization Guidelines, pathogens could be reduced through post treatment health-protection control measures such as drip irrigation, product washing, disinfection and produce peeling.
\end{abstract}

Keywords: wastewater treated effluent, eggplant, plastic mulch, microbial contamination.

Abbreviations: FW, freshwater; TW, treated wastewater; N_Mu, no mulch; Mu, mulch.

Introduction

The situation of increasing scarcity as well as the decline in the quality of water resources is projected to further deteriorate in the future (Balkhair, 2016; Qureshi et al., 2016; Mazzoni and Zaccagni 2019). Therefore, the reuse of treated wastewater can be an alternative practice, especially because the treatment and reuse practices would support the 2030 Agenda for Sustainable Development Goals, particularly Target 6.3 that deals with water quality, and the targets of SDG 2 of enhancing agricultural productivity and achieving zero hunger (UN General Assembly, 2015). Treated municipal wastewater is being used worldwide even for vegetable irrigation (Christou et al., 2017; Farhadkhani et al., 2018; Libutti et al., 2018; Mehmood et al., 2019). It is an interesting option for farmers; however, it could affect the yield and production quality. Safe wastewater reuse in agriculture has to overcome several challenges, such as better planning and management of reuse practices at farm level. In addition, the presence of contaminants could harm the environment, as well as the health of farmers and consumers (Cirelli et al., 2012; Gatta et al., 2016; Urbano et al., 2017; Decol et al., 2019; Petousi et al., 2019).

In Lebanon, the Food and Agriculture Organization of the United Nations (FAO) is working on providing technical assistance services in respect of the reuse of treated effluent in agriculture, and is proposing national guidelines. In this framework, FAO has worked on the wastewater treatment plant located in laat, the Bekaa Valley. The plant serves the city of Baalbek, and is the only working treatment plant that has secondary treatment (Conventional Treatment Process/Activated Sludge + Disinfection by Chlorination) 
before reuse for agriculture. However, the treated effluent contains fecal coliforms exceeding the limit of $1000 \mathrm{CF} / 100 \mathrm{~mL}$ proposed by the World Health Organization (WHO) that is permissible for the irrigation of all crops. In addition, nematodes exceed the limit of $1 / 1 \mathrm{~L}$. Accordingly, the treated water from laat is not suitable to grow vegetable crops as proposed by the Lebanese guidelines "FAO project UTF/LEB/019/LEB (2011) that were based on the WHO guidelines.

In the Bekaa Valley, the availability of freshwater is limited and therefore farmers have been irrigating crops with untreated wastewater. They will never stop growing vegetables, because it is a major source of their livelihood. Therefore, an experimental investigation was performed to test the feasibility of secondary treated municipal wastewater reuse for vegetable irrigation. The objective was to examine the risks to health (microbiological contamination of fruits) encountered when drip irrigated eggplant was grown using treated effluent and plastic mulch.

\section{Results and discussion}

\section{Emitter system performance}

In this study, it was important to assess the performance of the drip irrigation system in order to understand the behavior of drippers and their susceptibility to clogging when using treated wastewater. Table 1 shows the discharge of unclogged emitters $\left(Q_{t}\right)$, the mean discharge values to the entire field $\left(Q_{m}\right)$, the standard deviations (STDEV), the average discharge of the low quartile $\left(Q_{1 / 4}\right)$, the field emission uniformities (EU) as well as the reduction coefficients $\left(R_{d}\right)$ of mean discharge as evaluated.

For the plots irrigated with freshwater, $Q_{m}$ was 7.88 L.h $^{-1}$ at the beginning of the first season and reached 7.79 L.h $\mathrm{h}^{-1}$ at the end of the second season, indicating that there was no major fluctuation of discharge. In addition, differences up to $2.59 \%$ in terms of $R_{d}$ were detected and the emission uniformity remained high at the end of the second season, with a value of $92.27 \%$.

For the plots irrigated with treated wastewater, $Q_{m}$ was 7.81 ${\mathrm{L} . \mathrm{h}^{-1}}^{-1}$ at the beginning of the first season and reached 7.46 L.h${ }^{1}$ at the end of the second season. Differences up to $6.75 \%$ in terms of $R_{d}$ were detected and the emission dropped from $92.50 \%$ to $89.01 \%$ at the end of the second season. The lower performance of emitters delivering treated wastewater at the end of the second season could be related to excessive clogging because of salts and suspended particles in water. However, the obtained discharge reduction $R_{d}$ rates were still lower than the admissible value of $20 \%$ discharge variation, indicating that the quality of water has little effect on emitter performance. Moreover, such behavior could be also linked to the fact that filters were regularly cleaned, which protected the emitters from clogging. The results obtained are in agreement with the findings of Aiello et al. (2007) and Cirelli et al. (2012). Moreover, it should be highlighted that some authors, such as Li et al. (2012), have mentioned that chlorination is an effective method to reduce clogging in the emitters and to maintain good system performance when sewage effluent is applied through a drip irrigation system. Zhou et al. (2017) reported that the microbial growth of biofilms inside drip irrigation emitters could enhance emitter clogging, especially that reclaimed water typically contains large amounts of bacteria, and their excretions, the sticky extracellular polymeric substances. Sole-Torres et al. (2019) highlighted the fact that emitter clogging in drip irrigation was primarily affected by the interactions between underdrain design of the sand media filter, emitter location and irrigation time. Therefore, sand media filters could be recommended in order to achieve a higher retention of organic and inorganic solids when reclaimed effluents are used in drip irrigation systems.

\section{Water quality}

Table 2 shows the seasonal means of the physico-chemical, microbial characteristics and trace elements of the fresh and the treated water analyzed during the trial.

Going by the guidelines for interpretation of water quality for irrigation (FAO, 1985), salinity of fresh water was low and that of treated water was slight to moderate, but it was still suitable for irrigation. The values for the main physicochemical characteristics, particularly the $\mathrm{BOD}_{5}$ and the $\mathrm{COD}$ in treated water, were higher than the environmental limit values for surface water based on the Lebanese Ministry of Environment Decision 8/1 (MoE, 2001) as well as the limits for treated wastewater reuse proposed by the Lebanese guidelines (FAO, 2011). Nitrate content was low in treated effluent with a mean value of $0.86 \mathrm{mg}^{-1}{ }^{-1}$; however, it was high in fresh water with a mean value of $61 \mathrm{mg} . \mathrm{I}^{-1}$. Phosphorus level in treated effluent was most of the time low to moderate, with a mean of $4.19 \mathrm{mg} / \mathrm{L}$. Potassium level was high in treated water and sufficient to supply most of the nutrient requirement of field crops. For fresh water, both phosphates and potassium were low.

There was a high presence of fecal coliforms in the treated effluent, most of the time exceeding the limit of $1000 \mathrm{CF} / 100$ $\mathrm{mL}$ as proposed by the WHO, which is sufficient for the irrigation of all crops. Salmonella were present most of the time. Hookworm and Teania were not detected; however, ascaris were present in the samples. Nematodes had a strong presence, exceeding the limit of 1 helminth ova/1L as proposed per the Lebanese guidelines. The concentrations of micronutrients ( $\mathrm{Zn}, \mathrm{Cu}, \mathrm{Mn}$ ) and heavy metals ( $\mathrm{Pb}, \mathrm{Cd}, \mathrm{Cr}, \mathrm{Ni}$, and $\mathrm{Hg}$ ) were within the recommended maximum limits. Accordingly, the treated water from laat is of category III as proposed by the Lebanese guidelines and is not suitable for irrigation of vegetables, even those to be eaten cooked (FAO, 2011). However, this water could easily reach category II and even $I$ if adequately treated. Consequently, it is unfair to prevent farmers from growing vegetables, their main source of livelihood, and attention should be directed towards improvement of the management of the treatment plant and providing good quality water for farmers to use in their irrigation systems.

\section{Eggplant yield and quality parameters}

Table 3 reports the measured eggplant quantitative parameters, mainly the marketable yield and the number of fruits. $\mathrm{m}^{-2}$, as well as the fruit qualitative parameters that consisted of the fruit mean weight and the dry matter content.

When year was the source of variance, there was a significant difference only for the number of fruits. $\mathrm{m}^{-2}$ at $\mathrm{P} \leq 0.05$. Considering water quality as the source of variance, no significant difference was found in terms of number of fruits, marketable yield, mean fruit weight and dry matter percentage. However, the treatments under treated effluent gave more fruits. $\mathrm{m}^{-2}$, yield and mean fruit weight than the treatments under freshwater irrigation, with an increase of $3.98 \%, 10.74 \%$ and $5.63 \%$ respectively. Accordingly, an 
Table 1. Emitters' system performance indicators.

\begin{tabular}{|c|c|c|c|c|}
\hline & \multicolumn{2}{|c|}{ Beginning of the first season } & \multicolumn{2}{|c|}{ End of the second season } \\
\hline & Freshwater & Treated water & Freshwater & Treated water \\
\hline$Q_{t}\left(I . h^{-1}\right)$ & 8 & 8 & 8 & 8 \\
\hline$Q_{m}\left(I . h^{-1}\right)$ & 7.88 & 7.81 & 7.79 & 7.46 \\
\hline STDEV & 0.31 & 0.49 & 0.40 & 0.66 \\
\hline$Q_{1 / 4}\left(I . h^{-1}\right)$ & 7.52 & 7.22 & 7.19 & 6.64 \\
\hline EU (\%) & 95.43 & 92.50 & 92.27 & 89.01 \\
\hline $\operatorname{Rd}(\%)$ & 1.50 & 2.44 & 2.59 & 6.75 \\
\hline
\end{tabular}

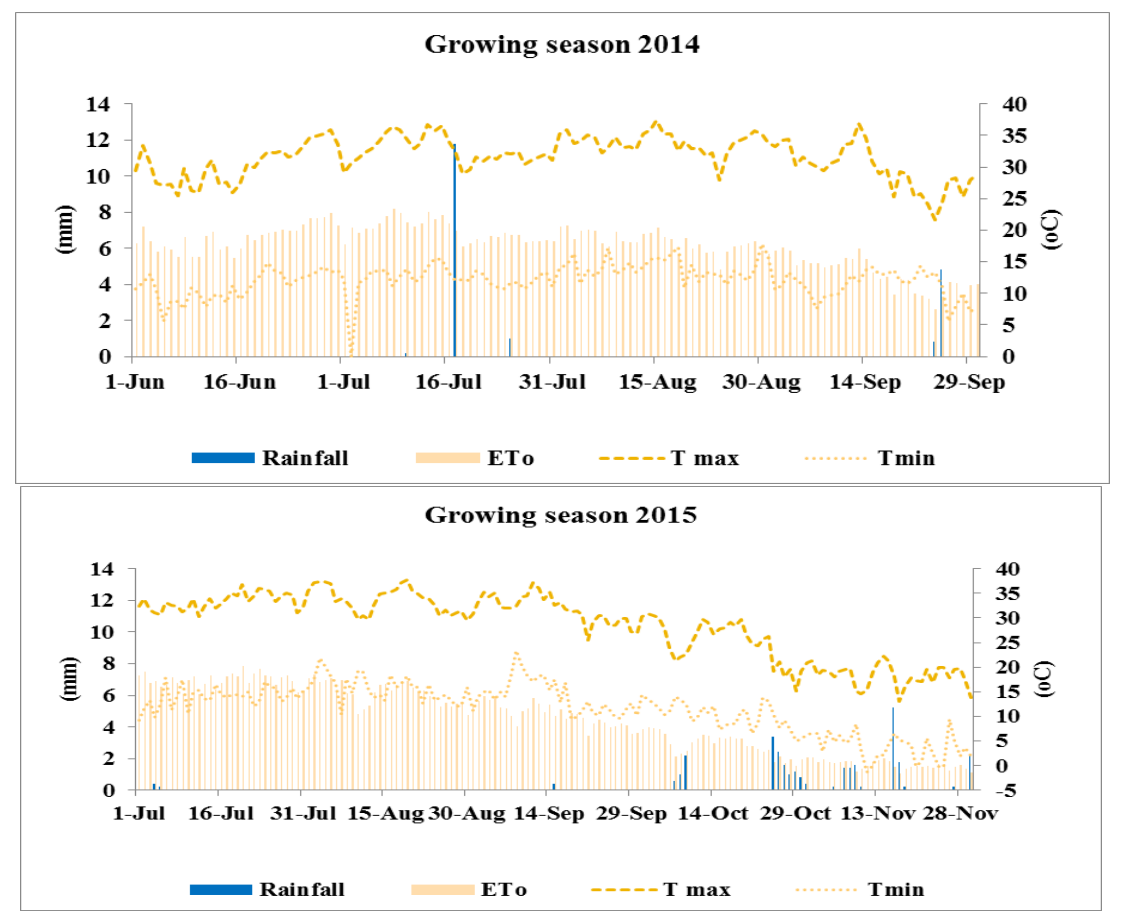

Fig 1. Rainfall (mm), maximum and minimum temperatures $\left({ }^{\circ} \mathrm{C}\right)$ and reference evapotranspiration (mm) for the growing seasons 2014 and 2015.

Table 2. Freshwater and treated effluent average quality and limit values for the reuse of TWW in Lebanon.

\begin{tabular}{|c|c|c|c|c|c|c|}
\hline & \multirow[b]{2}{*}{ FW } & \multirow[b]{2}{*}{ TW } & \multirow{2}{*}{$\begin{array}{l}\text { Environmental limit } \\
\text { values for surface water } \\
\text { based on MoE Decision } \\
8 / 1 \text { (MoE, 2001) }\end{array}$} & \multicolumn{3}{|c|}{$\begin{array}{l}\text { Effluent specifications for wastewater reuse in irrigation } \\
\text { based on proposed Lebanese guidelines (FAO, 2011) }\end{array}$} \\
\hline & & & & Water Category I & $\begin{array}{c}\text { Water } \\
\text { Category II }\end{array}$ & $\begin{array}{c}\text { Water } \\
\text { Category III }\end{array}$ \\
\hline \multicolumn{7}{|c|}{ Physico-chemical parameters (mg. $\mathrm{L}^{-1}$ ) } \\
\hline $\mathrm{pH}$ & 7.6 & 7.71 & $6-9$ & $6-9$ & $6-9$ & $6-9$ \\
\hline $\mathrm{EC}(\mathrm{mS} / \mathrm{cm})$ & 573 & 1541 & - & - & - & - \\
\hline COD & 40.00 & 251.00 & 125.00 & 125 & 250 & 250 \\
\hline $\mathrm{BOD}_{5}$ & 32.00 & 64.37 & 25.00 & 25 & 100 & 100 \\
\hline Nitrates & 61.00 & 0.86 & 90.00 & 30 & 30 & 30 \\
\hline Phosphates & 0.05 & 4.19 & 5.00 & - & - & - \\
\hline Potassium & 3.10 & 30.36 & - & - & _ & _- \\
\hline \multicolumn{7}{|l|}{ Pathogens in water } \\
\hline Fecal Coliform (CFU/100 mL) & 22.00 & $5.6 .10^{\wedge} 6$ & $<2000$ & $<200$ & $<1000$ & - \\
\hline Salmonella & Absent & Present & Absent & Absent & Absent & Absent \\
\hline Nematodes/helminths eggs & 2.00 & 5 & - & $<1 / L$ & $<1 / L$ & $<1 / L$ \\
\hline Hookworms/ml & 0.00 & 0 & - & - & - & - \\
\hline Ascaris lumbricoides/ml & 0.00 & 4 & - & - & - & - \\
\hline Taenia spp/ml (segment) & 0.00 & 0 & - & _ & _ & _ \\
\hline \multicolumn{7}{|l|}{ Trace metals (mg. $\mathrm{L}^{-1}$ ) } \\
\hline Zn & $<0.002$ & 0.03 & 5.00 & _ & - & - \\
\hline $\mathrm{Cu}$ & $<0.002$ & 0.01 & 0.50 & - & - & - \\
\hline $\mathrm{Pb}$ & $<0.002$ & 0.44 & 0.50 & _ & _ & - \\
\hline $\mathrm{Mn}$ & $<0.002$ & 0.02 & 1.00 & - & - & - \\
\hline $\mathrm{Ni}$ & $<0.002$ & 0.01 & 0.50 & - & _ & _ \\
\hline $\mathrm{Hg}$ & $<0.002$ & 0.0011 & 0.0500 & - & - & - \\
\hline $\mathrm{Cd}$ & $<0.002$ & 0.1789 & 0.2000 & - & - & - \\
\hline $\mathrm{Cr}$ & $<0.002$ & 0.03 & 2.00 & - & - & - \\
\hline
\end{tabular}


Table 3. Number of fruits, yield, mean fruit weight and dry weight as affected by irrigation water quality and agronomic practices.

\begin{tabular}{|c|c|c|c|c|c|}
\hline \multicolumn{2}{|c|}{ Source of variation } & \multirow{3}{*}{$\begin{array}{l}\text { Number of fruits } \\
\text { (fruits.m- }{ }^{2} \text { ) } \\
*\end{array}$} & \multirow{3}{*}{$\begin{array}{l}\text { Yield } \\
\qquad \begin{array}{c}\left.\text { (t.ha }{ }^{-1}\right) \\
\text { ns }\end{array}\end{array}$} & \multirow{3}{*}{$\begin{array}{l}\text { Mean fruit weight } \\
\text { (g) } \\
\text { ns }\end{array}$} & \multirow{3}{*}{$\begin{array}{r}\text { Dry weight } \\
\text { (\%) } \\
\text { ns }\end{array}$} \\
\hline & & & & & \\
\hline Year (Y) & & & & & \\
\hline & Y_2014 & $7.75 \mathrm{a}$ & 26.59 & 394.6 & 6.34 \\
\hline & Y_2015 & $6.06 \mathrm{~b}$ & 22.45 & 389.25 & 6.32 \\
\hline \multicolumn{2}{|c|}{ Water quality (WQ) } & ns & ns & ns & ns \\
\hline & FW & 6.77 & 23.27 & 381.19 & 6.35 \\
\hline & TW & 7.04 & 25.77 & 402.67 & 6.32 \\
\hline \multicolumn{2}{|c|}{ Agronomic practices (A) } & ns & $* *$ & $* *$ & ns \\
\hline & $\mathrm{N} \_\mathrm{Mu}$ & 6.54 & $21.87 \mathrm{~b}$ & $366.09 \mathrm{~b}$ & 6.30 \\
\hline & $\mathrm{Mu}$ & 7.27 & $27.17 \mathrm{a}$ & $417.77 \mathrm{a}$ & 6.36 \\
\hline$Y \times W Q$ & & ns & ns & ns & ns \\
\hline$Y \times A$ & & ns & ns & ns & ns \\
\hline$W Q \times A$ & & ns & ns & ns & ns \\
\hline \multicolumn{2}{|c|}{$Y \times W Q \times A$} & ns & ns & ns & ns \\
\hline
\end{tabular}

$\mathrm{ns},{ }^{*}, * *$ indicate respectively not significant, significant at $\mathrm{P} \leq 0.05$ and $\mathrm{P} \leq 0.01$; ns indicates not significant difference. Means followed by the same letter in each column are not significantly different according to the LSD test $(P=0.05)$.

Table 4. Mean values of bacteriological parameters on fruits for the two seasons.

\begin{tabular}{|c|c|c|c|c|}
\hline \multicolumn{3}{|c|}{ Bacteriological parameters (CFU.100 g g $^{-1}$ ) } & \multicolumn{2}{|c|}{ Mean values } \\
\hline & \multicolumn{4}{|c|}{ Season 2014} \\
\hline & Freshwater/No mulch & Freshwater/Mulch & Treated water/No mulch & Treated water/Mulch \\
\hline Fecal coliform & 0 & 0 & 50 & 120 \\
\hline Escherichia coli & 0 & 0 & 0 & 0 \\
\hline Fecal Streptococci & 0 & 0 & 0 & 0 \\
\hline \multirow[t]{3}{*}{ Salmonella } & Absent & Absent & Absent & Absent \\
\hline & \multicolumn{4}{|c|}{ Season 2015} \\
\hline & Freshwater/No mulch & Freshwater/Mulch & Treated water/No mulch & Treated water/Mulch \\
\hline Fecal coliform & 0 & 0 & 100 & 135 \\
\hline Escherichia coli & 0 & 0 & 0 & 0 \\
\hline Fecal Streptococci & 0 & 0 & 0 & 0 \\
\hline Salmonella & Absent & Absent & Absent & Absent \\
\hline
\end{tabular}

enhanced number of fruits could be attributed to the regular presence of an adequate level of potassium content in the treated effluent. When considering the agronomic practices as the source of variance, a significant difference was found between treatments under plastic mulch and those without mulch in terms of yield and mean fruit weight. The use of plastic mulch favored an increase in yield and mean fruit weight of $24.23 \%$ and $14.11 \%$, respectively. Mulch prevents the soil from drying out between irrigation events, and thus peaks in salt concentration in the root zone can be avoided. Such peaks are believed to have a negative impact on growth, and the use of mulch is expected to have a positive effect on yield under saline water irrigation (Karlberg et al., 2007). However, the number of fruits. $\mathrm{m}^{-2}$ and the dry matter content were not influenced by the practice. Similar findings were reported by Aiello et al. (2007), Cirelli et al. (2012) and Najafi et al. (2006). In addition, Akponikpe et al. (2011) found that the treated wastewater without mineral fertilizers resulted in $40 \%$ higher eggplant yield compared to freshwater. Considering the mulching practice, Aiello et al. (2013) confirmed that the use of plastic mulch resulted in higher yields.

\section{Eggplant microbial contamination}

The mean values of the results of microbiological analysis conducted on fruits (flesh+ skin) are reported in Table 4.

In general, the treatments under freshwater irrigation were not contaminated by fecal coliforms, E. coli, fecal streptococci or salmonella for either of the seasons. The treatments irrigated with treated wastewater showed no contamination in terms of fecal streptococci, salmonella and E. coli. Many authors have reported the absence of $\mathrm{E}$. coli on vegetables that were drip irrigated with treated wastewater, such as artichoke (Gatta et al., 2016), broccoli and tomato (Libutti et al., 2018), eggplant (Cirelli et al., 2012), fennel (Lonigro et al., 2016) and lettuce (Urbano et al., 2017).

However, the fruits were contaminated with fecal coliforms that were present at a concentration less than 200 CFU.100 g 1 .

Concerning the use of plastic mulch, some difference was noticed in terms of microbiological contamination of the fruits. The results obtained confirm that the mulched surface could enhance the microbial biomass, thus causing higher product contamination, as cited by Aiello et al. (2008).

Considering that a non-negligible level of contamination on fruits was found, the results confirm that a treated effluent cannot be used for irrigation without proper treatment, an additional disinfection and also some post-treatment measures (WHO, 2006). In fact, following the WHO Guidelines (2006), pathogens could be reduced through post treatment health-protection control measures such as drip irrigation, product washing, disinfection and produce peeling.

\section{Materials and methods}

\section{Experimental site and climate}

The field experiment was carried out during two growing seasons, 2014 and 2015, in the village of Laat located in the 
Bekaa Valley, Lebanon (34.048410N lat., 36.143973E long.) The experiment was conducted in a field near the Wastewater Treatment Plant (WWTP) that has been serving the village for 2 years. The WWTP treats municipal wastewater according to a secondary treatment through activated sludge process, followed by disinfection through chlorination.

The climate is typically Mediterranean, characterized by a hot-dry season from April to October and cold for the remainder of the year. The main weather parameters were obtained from a standard agro-meteorological station located in the region. The weather regimes, in terms of minimum and maximum temperatures (Tmin and Tmax), rainfall $(R)$ and reference evapotranspiration (ETo) during the growing season are given in Fig 1.

In general, overall average air temperature during the growing cycle in 2014 was $21.88^{\circ} \mathrm{C}$ and the total precipitation was $18.6 \mathrm{~mm}$, registered mainly during a few irrigation events, particularly on 17 July and 25 September. For the growing season in 2015, the overall average air temperature was $21.98^{\circ} \mathrm{C}$ and the total precipitation amount was $15.6 \mathrm{~mm}$. The soil of the study area is sandy clay: containing $53.51 \%$, $35.19 \%$ clay and $11.3 \%$ silt. The total available water holding capacity within the top $1 \mathrm{~m}$ of soil profile is $90 \mathrm{~mm}$. The $\mathrm{pH}$ was 7.81, the electrical conductivity was $0.54 \mathrm{dS} . \mathrm{m}^{-1}$, the organic matter content was $1.85 \%$, while the percentage of total nitrogen was $0.18 \%$, and the phosphorus and potassium content was 28.70 and 405.30 ppm, respectively.

\section{Treatments and agronomic management}

The experiment was carried out to assess the response of drip irrigated eggplant grown under two water quality regimes: freshwater (FW) and treated wastewater (TW) and two agronomic practices: no mulch (N_Mu) and use of plastic mulch $(\mathrm{Mu})$. The purpose was to investigate the effect of treated wastewater irrigation on eggplant yield and quality attributes and to check if the presence of plastic mulch could constitute a protection measure against the microbial contamination of fruits by preventing them from coming into direct contact with irrigation water.

The planting density was $1.25 \mathrm{plant} / \mathrm{m}^{2}$ according to the standard practices in the Bekaa Valley. For season 2014, planting of seedlings occurred on 10 June, while three harvests were completed on: 14 August, 23 August and 9 September. For season 2015, planting was done on 24 July and four harvests were achieved on: 29 September, 8 October, 20 October and 3 November. The eggplant was harvested at commercial maturity.

Treatments were arranged in a split plot design with four replicates. Water quality regime was the main plot factor, while agronomic practices were the subplot factors. Each experimental plot was $5 \mathrm{~m} \times 5 \mathrm{~m}$.

\section{Irrigation management}

Irrigation was managed using an Excel-based irrigation tool (Todorovic, 2006) that employs meteorological, soil and crop data for a day-by-day estimation of the soil water balance in the effective root zone. Reference evapotranspiration was calculated on a daily basis from measured weather data using the FAO Penman-Monteith equation (Allen et al., 1998). The $\mathrm{Kc}$ values were determined on the basis of in-field observations of crop phenological stages and using the FAO 56 data. The management allowable depletion was assumed to be 0.45 of total available water $(P=0.45)$ during the whole growing cycle, as suggested in FAO 56. The crop was kept under optimal water conditions during the whole season.

\section{Components of the irrigation system}

All the plots were equipped with low polyethylene surface laterals with $16 \mathrm{~mm}$ external diameter. All the laterals were supplied by in-line drippers (theoretical discharge rate of $8 \mathrm{~L}$ $\mathrm{h}^{-1}$ at a pressure of $100 \mathrm{kPa}$ ) with emitters spaced at $0.40 \mathrm{~m}$. The spacing between laterals was $1 \mathrm{~m}$. The experiment was equipped with separate reservoirs and head units for the treatments using freshwater and those using treated effluent. Each head unit consisted of a pump, venturi type fertilizer tank, disc filter and pressure gauges. Filters were manually cleaned.

\section{Emitter system performance}

To monitor the drip line performance, the emission uniformity (EU \%) and reduction factor ( $\left.R_{d} \%\right)$ were determined. The EU is the ratio between the average discharge of the emitters in the bottom 25th percentile in terms of discharge $\left(Q_{\min 1 / 4}\right)$ and that of all the emitters $\left(Q_{m}\right)$, both expressed in L.s ${ }^{-1}$ (Keller and Karmeli, 1975):

$\mathrm{EU}=100 \bullet Q_{\min 1 / 4} / Q_{m}$

The EU was determined at the beginning of the first season and at the end of the second season by measuring the discharge of 5 emitters for each lateral supplying fresh and treated water.

The $R_{d}(\%)$ is defined as:

$R_{d}=100 .\left(1-Q_{m} / Q_{t}\right)$

where $Q_{t}\left(\right.$ L.s $\left.S^{-1}\right)$ is the discharge $\left(8\right.$ L.S $\left.^{-1}\right)$ of new unclogged emitters operating at the same pressure $(100 \mathrm{kPa})$. Furthermore, standard deviations (STDEV) of drip lines' discharge rate were computed.

\section{Water sampling}

The main chemical and microbial characteristics of both kinds of water (FW and TW) were monitored during the irrigation period at two-week intervals. Samples were collected at the beginning of the irrigation system using sterile $1000 \mathrm{~mL}$ glass bottles. The bottles were stored at $4{ }^{\circ} \mathrm{C}$ and sent to laboratory for analysis.

Standard methods for the examination of water and wastewater (APHA, 1998) were followed in the laboratory to measure the chemical properties of water and for the microbiological analysis: total coliforms (TC), fecal coliforms (FC), Escherichia coli (E. coli). Salmonella and helminth eggs were examined according to the methodology described by Giammanco et al. (2002). The samples were also analyzed for their content of trace elements, using atomic absorption spectrophotometery methodology.

\section{Crop yield, quality and microbial contamination of fruits}

The effects of the quality of irrigation water (FW and TW) and agronomic practices (mulch and no mulch) on crop production and their interactions were analyzed. The analyses measured the marketable yield and the number of marketable fruits. In addition, the main crop quality characteristics were evaluated for 10 marketable fruits of each replicate. The evaluated quality parameters for the eggplants were unit mean weight and dry matter (by drying fruits in ventilated oven at $70^{\circ} \mathrm{C}$ until constant weight).

Fruits were harvested to measure microbial contamination. In the laboratory, $100 \mathrm{~g}$ of fruits, including fruit skin and flesh, were homogenized with $900 \mathrm{~mL}$ of sterile water by a stomacher. Then, ten-fold dilution was conducted within the same medium. Fecal coliform, E. Coli and fecal streptococci 
were measured using membrane filtration techniques (APHA, 1998). The Salmonella detection protocol was done according to Giammanco et al. (2002).

\section{Statistical analysis}

Two factors (water quality regime and agronomic practices) were analyzed together, according to a split plot experimental design. Each dependent variable was evaluated for normal distribution according to the Shapiro-Wilk test at 0.05 probability level.

Combined analyses were instead run over 2014 and 2015, after verifying the homogeneity of error variances using Bartlett's chi-square test (Gomez and Gomez, 1984). The Year was considered as a random effect.

Statistical analyses were performed through the GLM procedure of SAS/STAT by using the correct error term to evaluate each factor and interaction. Least significant difference (LSD) at 0.05 probability level was used as mean separation test.

\section{Conclusion}

This study shows that an integrated planning approach that takes into account the technological aspects of the irrigation system as well as the production and contamination issues is essential for the safe irrigation of vegetable crops. The microbiological quality of the products should also be maintained. As suggested by the World Health Organization in 2006, these levels of microbial contamination could be reduced by applying post-treatment health-protection control measures to reduce the risk of microbial contamination to acceptable levels. From the agronomical point of view, eggplant was grown successfully under treated wastewater, resulting in $10 \%$ yield increase when compared to yield from crops under freshwater irrigation. In addition, when irrigated with treated effluent the eggplant yield was found not to be sensitive to the EU variability. Finally, several elements must be considered when treated wastewater is used in agriculture, including the presence of pathogens and chemical contaminants on the irrigated products as well as the impact of treated wastewater on soil properties and on the irrigation system equipment. Continued research and development will help improve and increase the use of treated wastewater for irrigation and will address the concerns of the general public.

\section{Acknowledgments}

This work was conducted within the framework of the Food and Agricultural Organization of the United Nations project "GCP/INT/124/ITA: Coping with Water Scarcity - The Role of Agriculture. Phase III: Strengthening National Capacities".

\section{References}

Aiello R, Cirelli GL and Consoli S (2007) Effects of reclaimed wastewater irrigation on soil and tomato fruits: a case study in sicily (Italy). Agric Water Manag. 93: 65-72.

Aiello R, Cirelli G, Consoli S, Licciardello F, Toscano A (2013) Risk assessment of treated municipal wastewater reuse in Sicily. Water Sci Technol. 89-98.

Akponikpe PBI, Wima K, Yacouba H, Mermoud A (2011) Reuse of domestic wastewater treated in macrophyte ponds to irrigate tomato and eggplant in semi-arid West-Africa: benefits and risks. Agric. Water Manag. 98: 834-840.
Allen RG, Pereira LS, Raes D, Smith M (1998) Crop Evapotranspiration. Guidelines for Computing Crop Water Requirements (Irrigation and Drainage Paper 56). Food and Agriculture Organization, Rome.

APHA (1998) Standard methods for the examination of water and wastewater, 20th Ed. American Public Health Association, Washington D.C.

Balkhair KS (2016) Microbial contamination of vegetable crop and soil profile in arid regions under controlled application of domestic wastewater. Saudi J Biol Sci. 23: 83-92.

Christou A, Karaolia P, Hapeshi E, Michael C, Fatta-Kassinos D (2017) Long-term wastewater irrigation of vegetables in real agricultural systems: concentration of pharmaceuticals in soil, uptake and bioaccumulation in tomato fruits and human health risk assessment. Water Res. 109: 24-34.

Cirelli GL, Consoli S, Licciardello F, Aiello R, Giuffrida F, Leonardi C (2012) Treated municipal wastewater reuse in vegetable production. Agric Water Manag. 104: 163-170.

Decol LT, López-Gálvez F, Truchado P, Tondo EC, Gil MI, Allende A (2019) Suitability of chlorine dioxide as a tertiary treatment for municipal wastewater and use of reclaimed water for overhead irrigation of baby lettuce. Food Control. 96: 186-193.

Elgallal M, Fletcher L, Evans B (2016) Assessment of potential risks associated with chemicals in wastewater used for irrigation in arid and semiarid zones: a review. Agric Water Manag. 177: 419-431.

FAO (1985) Water quality for agriculture. R.S. Ayers and D.W. Westcot. Irrigation and Drainage Paper 29 Rev. 1. FAO, Rome. $174 \mathrm{p}$.

FAO (2011) Effluent specifications for wastewater reuse in irrigation based on proposed Lebanese guidelines.

Farhadkhani M, Nikaeen M, Yadegarfar G, Hatamzadeh M, Pourmohammadbagher H, Sahbaei Z, Rahmani HR (2018) Effects of irrigation with secondary treated wastewater on physicochemical and microbial properties of soil and produce safety in a semi-arid area. Water Res. 144: 356364.

Gatta G, Libutti A, Beneduce L, Gagliardi A, Disciglio G, Lonigro A, Tarantino E (2016) Reuse of treated municipal wastewater for globe artichoke irrigation: Assessment of effects on morpho-quantitative parameters and microbial safety of yield. Sci. Hortic. 213: 55-65.

Giammanco G, Pignato S, Alliot M, Polgatti M (2002) Rapid method for Salmonella enumeration in wastewater. In: Proc. of the International Symposium on Salmonella and Salmonellosis, St. Brieuc, France, 29-31 May.

Gomez KA, Gomez AA (1984) Statistical Procedures for Agricultural Research. Second edition. An International Rice Research Institute Book. John-Wiley \& Sons, New York.

Karlberg L, Rockström J, Annandale JG, Martin Steyn J (2007) Low-cost drip irrigation- A suitable technology for southern Africa? An example with tomatoes using saline irrigation water. Agric Water Manag. 89: 59-70.

Keller D, Karmeli J (1975) Trickle irrigation design, Rain bird Mfg corporation. Glendora.

Libutti A, Gatta G, Gagliardi A, Vergine P, Pollice A, Beneduce L, Disciglio G, Tarantino E (2018) Agro-industrial wastewater reuse for irrigation of a vegetable crop succession under Mediterranean conditions. Agric Water Manag. 196: 1-14.

Li JS, Li YF, Zhang H (2012) Tomato Yield and Quality and Emitter Clogging as Affected by Chlorination Schemes of Drip Irrigation Systems Applying Sewage Effluent. J Integr Agric. 1744-1754. 
Lonigro A, Rubino P, Lacasella V, Montemurro N (2016) Faecal pollution on vegetables and soil drip irrigated with treated municipal wastewaters. Agric Water Manag. 174: 66-73.

Mazzoni A, Zaccagni S (2019) Status of Water Resources and Human Health in the Middle East and North Africa Region: An Integrated Perspective. Encyclopedia of Environmental Health (Second Edition): 805-817.

Mehmood A, Mirza MA, Choudhary MA, Kim KH, Raza W, Raza $N$, Lee SS, Zhang M, Lee JH, Sarfraz, M (2019) Spatial distribution of heavy metals in crops in a wastewater irrigated zone and health risk assessment. Environ Res. 168: 382-388.

MoE (2001) Lebanese standards for wastewater treatment and release. Decision issued by the Ministry of Environment: Decision 8/1 on January 30, 2001.

Najafi P, Mousavi SF, Feizi M (2006) Effects of using sub surface drip in irrigation of tomato and eggplant with treated municipal wastewater. Iranian Journal of Soil and Waters Sciences. 20: 155-163.

Pedrero F, Kalavrouziotis I, Alarcòn JJ, Koukoulakis P, Asano T (2010) Use of treated municipal wastewater in irrigated agriculture: Review of some practices in Spain and Greece. Agric. Water Manage. 97: 1233-1241.

Petousi I, Daskalakis G, Fountoulakis MS, Lydakis D, Fletcher L, Stentiford El, Manios T (2019) Effects of treated wastewater irrigation on the establishment of young grapevines. Sci Total Environ. 658: 485-492.
Qureshi AS, Hussain MI, Ismail S, Khan QM (2016) Evaluating heavy metal accumulation and potential health risks in vegetables irrigated with treated wastewater. Chemosphere. 163: 54-61.

Sole-Torres C, Puig-Bargués J, Duran-Ros M, Arbat G, Pujol J, deCartagena FR (2019) Effect of different sand filter underdrain designs on emitter clogging using reclaimed effluents. Agric Water Manag. 223: 105683.

Todorovic M (2006) An Excel-based tool for real time irrigation management at field scale. In: Proceedings of International Symposium on "Water and Land Management for Sustainable Irrigated Agriculture", Cukurova Univ., Adana, Turkey, 4-8 April 2006.

UN General Assembly (2015) Transforming Our World: The 2030 Agenda for Sustainable Development. United Nations New York, New York.

Urbano VR, Mendonc A TG, Bastos RG, Souza CF (2017) Effects of treated wastewater irrigation on soil properties and lettuce yield. Agric Water Manag. 181: 108-115.

WHO (2006) Guidelines for the Safe Use of Wastewater, Excreta and Grey Water. World Health Organization, Geneva.

Zhou B, Wang T, Li Y, Bralts V (2017) Effects of microbial community variation on bio-clogging in drip irrigation emitters using reclaimed water. Agric Water Manag. 194: 139-149. 